\title{
PENERAPAN PENDEKATAN KONTEKSTUAL BERBANTUAN MEDIA PEMBELAJARAN DALAM MENINGKATKAN MINAT DAN PEMAHAMAN KONSEP FISIKA SISWA
}

\author{
Yusdarina $^{1}$, Syamsuriana Basri ${ }^{2}$ \\ ${ }^{1,2}$ Program Studi Pendidikan Fisika Universitas Muslim Maros \\ yusdarina@umma.ac.id
}

\begin{abstract}
Application of a Contextual Approach Assisted by Learning Media in Increasing Student Interest and Understanding of Physics Concepts. This research is a research of class actions carried out in class X SMK Muhammadiyah Bungoro. Based on the results of the research that has been done it is known that the application of a contestual approach assisted by learning media can increase the interest in learning and understanding the concept of physics students. Analysis of the interest in learning obtained results that before the action of the interest category students are quite interested and after the action is carried out in the first cycle and Cycle II the student's learning interest rises to the category of Interested . Understanding the concept of students before the action is still relatively low, after the action carried out in the first cycle of classical absorption value of the student becomes increased. This study succeeded in increasing the interest in learning and understanding the physics concept of grade $\mathrm{X}$ students.
\end{abstract}

Keywords : interest in learning, understanding concepts, contextual approaches, learning media

\begin{abstract}
Abstrak : Penerapan Pendekatan Kontekstual Berbantuan Media Pembelajaran dalam Meningkatkan Minat dan Pemahaman Konsep Fisika Siswa. Penelitian ini merupakan penelitan tindakan kelas yang dilakukan pada kelas X SMK Muhammadiyah Bungoro. Berdasarkan hasil penelitian yang telah dilakukan diketahui bahwa Penerapan pendekatan kontestual berbantuan media pembelajaran dapat meningkatkan minat belajar dan pemahaman konsep fisika siswa. Analisis minat belajar yang dilakukan diperoleh hasil bahwa sebelum dilakukan tindakan kategori minat siswa cukup berminat dan setelah dilakukan tindakan pada siklus I dan Siklus II minat belajar siswa naik menjadi kategori Berminat . Pemahaman konsep siswa sebelum dilakukan tindakan masih tergolong rendah, setelah dilakukan tindakan pada siklus I nilai daya serap klasikal siswa menjadi mengalami peningkatan. Penilitian ini berhasil meningkatkan minat belajar dan pemahaman konsep fisika siswa kelas X. Hasil respon siswa terhadap pembelajaran pada siklus I dan II siswa merasa senang dengan diterapkannya pendekatan kontekstual berbantuan media pembelajaran.
\end{abstract}


Kata Kunci : minat belajar, pemahaman konsep , pendekatan kontekstual, media

pembelajaran

Fisika sebagai salah satu cabang dari ilmu pengetahuan alam yang memberi kontribusi pada perkembangan tekhnologi saat ini haruslah mendapat perhatian sebab, ketersedian tenaga ahli dibidang fisika akan mendorong perkembangan tekhnologi pada bangsa kita. Melalui sekolah ilmu fisika diajarkan kepada siswa sebagai cabang dari ilmu pengetahuan alam atau yang dikenal dengan pelajaran sains namun, bagi sebagian siswa ilmu fisika dinilai sulit sebab selain membutuhkan hafalan juga membutuhkan kemampuan matematika yang baik, akibatnya sebagian besar siswa tidak berminat dalam mempelajari fisika. Alasan tersebut berakibat pada rendahnya pemahaman konsep fisika siswa, karena siswa menganggap cara belajar fisika adalah dengan menghafalkan rumus-rumus yang ada.

Realitas yang terjadi adalah proses belajar hanya berpusat pada guru (teacher centered) dan berakibat pada rendahnya kemampuan berpikir siswa. Guru menjadi pusat informasi, siswa tidak membangun pemahamannya sendiri karena selalu mengharapkan pengetahuan hanya datang dari guru, siswa pasif dalam menggali pengetahuannya. Hasil observasi lapangan di SMK Muhammadiyah Bungoro diketahui proses belajar berlangsung dengan metode ceramah, sesekali tanya jawab dan mengerjakan soal-soal. Hasil belajar fisika siswa kelas $\mathrm{X}$ tahun pelajaran 2018/2019 dalam kategori rendah yakni rata-rata 5,51 yang terdiri atas tujuh kelas. Wawancara dengan beberapa orang siswa juga menyebutkan siswa merasa sulit mempelajari fisika dan tidak senang, eksperimen sangat jarang dilaksanakan.

Hasil angket minat belajar siswa pada salah satu kelas yakni kelas $\mathrm{X}$ Listrik menunjukan $58.97 \%$ siswa kurang berminat dan $41.03 \%$ cukup berminat. Minat belajar pada diri siswa perlu ditingkatkan sebab tidak akan ada perkembangan mental tanpa adanya minat. Minat adalah dasar dari perhatian dan pemahaman . Menurut Basri (2019: 85) dengan adanya media pengajaran dan pembelajaran, siswa dapat belajar dengan mudah dan merasa senang dalam mengikuti pelajaran. Pada SMK Muhammadiyah Bungoro sesungguhnya mempunyai banyak fasilitas belajar atau media yang bisa digunakan oleh guru dalam mengajar hanya saja, belum difungsikan sebagai mana mestinya. Media pembelajaran dapat membantu guru menjelaskan atau memvisualisasikan sesuatu kepada siswa sehingga siswa lebih mudah untuk memahami materi yang diajarkan. Pemahaman konsep perlu ditanamkan kepada siswa dalam mempelajari fisika sebab ilmu fisika bukanlah seperangkat pelajaran yang hanya dihafalkan, sebab dengan hafalan siswa tidak akan bisa melihat makna dari ilmu fisika yang sangat berkaitan dengan kehidupan. Berdasarkan hasil analisa dan observasi yang dilakukan perlu diupayakan perbaikan untuk meningkatkan minat belajar dan pemaham konsep siswa, salah satu upaya tersebut adalah dengan menerapkan Pendekatan Kontekstual berbantuan Media pembelajaran.

Pendekatan Kontekstual dipilih sebab pendekatan ini lebih relevan digunakan untuk membantu siswa memahami fisika, dengan pendekatan kontekstual peran guru adalah fasilitator yang akan menghubungkan pengetahuan siswa dengan kehidupannya. Peran media dalam prosesnya nanti akan membantu guru menyajikan pelajaran sehingga rasa ingin tahu dan antusiasme siswa meningkat yang akhirnya akan mendorong tingkat minat belajar siswa.

Hasil penelitian Amirullah, Bunga Dara Amin, Nurlina 2013 Universitas Muhammadiyah Makassar dengan judul "Penerapan pendekatan kontekstual untuk meningkatkan hasil belajar fisika siswa kelas VII SMP Negeri 3 Satap Liukang Kalmas Kabupaten Pangkep" mengatakan bahwa Terdapat peningkatan yang signifikan antara hasil belajar fisika siswa sebelum diajar dengan menerapkan pendekatan Kontekstual dan setelah diajar dengan menerapkan pendekatan Kontekstual. Sehingga pendekatan Kontekstual dapat dijadikan sebagai salah satu alternatif untuk meningkatkan hasil belajar fisika bagi siswa.

Hasil penelitian Ahsan Irawan, Muh. Arsyad, Khaeruddin 2011 Universitas Negeri Makassar dengan judul "Upaya meningkatkan 
hasil belajar fisika melalui penerapan pendekatan

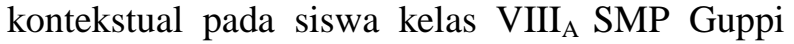
Samata kabupaten gowa" mengatakan bahwa hasil belajar fisika siswa dengan menggunakan pendekatan kontekstual pada siswa kelas VIIIA SMP Guppi Samata Kabupaten Gowa dapat meningkat dari siklus I ke siklus II yaitu sebesar skor rata-ratanya sebesar 61,35 meningkat menjadi 71,54 dan persentase ketuntasannya sebesar 38,46 \% meningkat menjadi 88,46\%. Sehingga Pendekatan Kontekstual layak digunakan sebagai acuan dalam Proses Pembelajaran Fisika di Kelas VIII.

Hasil penelitian Nur Afifah, Ngurah Ayu Nyoman Murniati, dan Susilawat 2013 IKIP PGRI Semarang dengan judul "Penerapan Pendekatan Kontekstual Menggunakan Media Video Untuk Meningkatkan Hasil Belajar Fisika Pada Kelas XI RPL 1 SMK N 8 Semarang" mengatakan bahwan penggunaan pendekatan kontekstual dengan media dapat meningkatkan hasil belajar siswa dan keaktifan siswa kelas XI RPL 1 SMK N 8 Semarang pada semester 2 tahun pelajaran 2012/2013. Hal ini dikarenakan pada penelitian tindakan kelas yang telah dilakukan siswa mampu menyelesaikan tugas yang telah diberikan guru dengan baik, siswa merasa senang terhadap proses pembelajaran dengan pedekatan kontekstual menggunakan media video yang menjadikan suasana kelas menjadi lebih hidup dengan adanya interaksi positif antar siswa yaitu dengan berdiskusi kelompok dan juga suasana kelas yang menyenangkan.

Berdasarkan uraian diatas, maka perlu diadakan penelitian "Penerapan pendekatan kontekstual berbantuan media pembelajaran dalam meningkatkan minat dan pemahaman konsep fisika siswa"

\section{METODE PENELITIAN}

Jenis penelitian ini adalah penelitian tindakan kelas dengan menerapkan model kurt lewin yang dikembangkan oleh Kemmis dan Mc.Taggart. Subjek penelitian ini adalah siswa kelas X Listrik SMK Muhammadiyah 1 Bungoro Kabupaten Pangkep tahun pelajaran 2019/2020 yang berjumlah 35 siswa laki-laki. Sedangkan objek penelitian adalah minat dan pemahaman konsep fisika siswa.

Pelaksanaan penelitian dilakukan bersiklus. Setiap siklus dilaksanakan sesui dengan perubahan tingkah laku yang ingin dicapai. Sebelum melaksanakan penelitian terlebih dahului dilakukan tes (tes awal). Hasil tes ini digunakan untuk mengetahui kemampuan awal siswa serta digunakan untuk menentukan kelompok. Berdasarkan refleksi awal dilaksanakan tindakan dengan prosedur: 1) Perencanaan, 2) Pelaksanaan tindakan, 3) Observasi, 4) Refleksi dalam setiap siklus.

Pada tahapan perencanaan dibuat Rencana Pelaksanaan Pembelajaran (RPP), skenario pembelajaran yang menggunakan pendekatan kontekstual berbantuan media pembelajaran, Lembar Kerja Siswa (LKS), alat evaluasi berupa tes pemahaman konsep untuk mengetahui tingkat penguasaan konsep siswa terhadap materi dan kuisioner minat belajar untuk mengetahui seberapa besar minat siswa terhadap pembelajaran.

Kegiatan yang dilakukan pada tahap tidakan adalah melaksanakan pembelajaran sesuai skenario pembelajaran yang telah dirancang, dengan menerapkan pendekatan kontekstual dan media yang relevan yang telah disesuaikan dengan kondisi tempat penelitian berlangsung. Jumlah pertemuan disesuaikan dengan kedalaman materi ajar.

Pengumpulan data dilakukan melalui Tes yang diberikan kepada siswa setiap akhir tindakan (siklus), Observasi selama proses pembelajaran berlangsung baik siklus I maupun siklus II dan Kuisioner untuk mengumpulkan data minat belajar dan respon siswa terhadap proses pembelajaran dengan pendekatan kontekstual berbantuan media pembelajaran. Data dianalisis secara deskriptif kualitatif dan kuantitatif.

\section{HASIL DAN PEMBAHASAN}

Penerapan pendekatan kontekstual berbantuan media pembelajaran merupakan alternatif untuk dapat meningkatkan minat belajar dan pemahaman konsep fisika siswa, sesuai dengan hasil penelitian yang telah dilakukan dan dapat dijelaskan sebagai berikut. Dari hasil 
Karst : Jurnal Pendidikan Fisika dan Terapannya

Volume 3 | Nomor 2 | 69

p-ISSN: 2622-9641 e-ISSN: 2655-1276

analisis tes awal pemahaman konsep siswa masih rendah disebabkan siswa belajar dengan mengandalkan hafalan teori saja, dalam proses belajar siswa tidak terlibat dalam membangun pemahamannya sebab aktivitas utama dilakukan oleh guru. Siswa tidak terbiasa menemukan sesuatu yang berguna bagi dirinya, pengalaman siswa dalam membangun pemahamannya sangat rendah. Hasil angket minat belajar yang diberikan pada pra tindakan menjelaskan bahwa minat belajar fisika siswa masih rendah, karena proses belajar yang berlangsung kurang memaksimalkan aspek afektif dan psikomotor siswa. Siswa cenderung terus dituntun, kemandirian dalam belajar belum ada, proses belajar yang berlangsung juga dinilai kurang menyenangkan bagi siswa bahkan ada kecenderungan membosankan dan hal-hal tersebut membuat siswa malas untuk mengkaji fisika lebih jauh.

Hasil analisis pada siklus I menjelaskan terjadi kemajuan kemampuan pemahaman konsep siswa dan juga minat belajar, penerapan pendekatan kontekstual berbantuan media pembelajaran menciptakan ruang kelas yang didalamnya siswa menjadi peserta aktif bukan peserta pasif. Kemampuan afektif dan psikomotor siswa juga mengalami kemajuan. Pada siklus II juga terjadi peingkatan, pemahaman konsep dan minat belajar siswa mengalami kemajuan yang lebih maksimal dibanding siklus I. Hal ini menunjukan bahwa penerapan pendekatan kontekstual berbantuan media pembelajaran cukup efektif digunakan untuk meningkatkan minat belajar dan pemahaman konsep fisika siswa.

Siklus I, kegiatan siswa masih belum aktif secara keseluruhan. Hal ini dapat terlihat dari banyaknya siswa yang belum dapat bekerjasama dengan baik antar sesama teman pada kelompok belajarnya dan juga dengan adanya siswa yang mendominasi dalam mengerjakan LKS sehingga siswa lain hanya bersifat pasif demikian pula pada

\section{DAFTAR PUSTAKA}

Afifah, Nur, dkk. 2013. Penerapan Pendekatan Kontekstual Menggunakan Media Video Untuk Meningkatkan Hasil Belajar Fisika Pada Kelas XI RPL 1 SMK N 8 Semarang. Jurnal Pendidikan Fisika, 1-7. saat eksperimen beberapa siswa masih mendominasi pembelajaran dan siswa yang lain cenderung pasif. Pada awal pertemuan peneliti memotivasi siswa dengan menyajikan vidio pembelajaran yang memberikan gambaran awal apa yang akan mereka pelajari dan kaitannya dengan kehidupan siswa sehingga hal ini menarik minat mereka untuk mencari informasi lebih banyak lagi tentang apa yang akan mereka pelajari.

Siswa dibagi dalam 6 kelompok berdasarkan hasil tes awal, kelompok siswa terdiri dari tim yang heterogen dalam segala hal terutama kemampuan sehingga setiap kelompok mendapat seorang siswa dengan kemampuan tinggi yang dapat memudahkan pengelolaan kelas. Hasil analisis dari siklus satu menunjukan kemajuan perkembangan aspek kognitif, afekti, dan psikomotor siswa. Siklus I dinilai cukup efektif membantu siswa dalam belajar, namun untuk mendapatkan hasil yang lebih maksimal penelitian dilanjutkan pada siklus II.

Pada siklus II siswa juga menunjukan kemajuan sebab siswa mulai bisa beradaptasi dengan penerapan metode yang peneliti gunakan. Pada siklus II Minat belajar dan pemahaman konsep siswa juga meningkat dibanding siklus I. Di siklus II siswa dan peneliti sudah bisa mengorganisir dirinya sehingga semua subjek belajar mampu menempatkan diri sesuai perannya masing - masing. Kemajuan siswa dalam kerjasama, kemandirian belajar, dan mengkomunikasikan ide mengalami perkembangan yang cukup menggembirakan. Penerpan pendekatan kontekstual berbantuan media pembelajaran memberikan efek positif baik bagi siswa dan juga peneliti. Siswa menjadi lebih bersemangat dalam belajar sedangkan peneliti tertantang untuk membuat suasana belajar lebih kreatif.

Amirullah, dkk. 2013. Penerapan pendekatan kontekstual untuk meningkatkan hasil belajar fisika siswa kelas VII SMP Negeri 3 Satap Liukang Kalmas Kabupaten Pangkep. Jurnal Pendidikan Fisika Vol.1 N0.3, 197-201.

Aswan, Syaiful. 2006. Strategi BelajarMengajar. Jakarta: Rineka Cipta 
Karst : Jurnal Pendidikan Fisika dan Terapannya Volume 3 | Nomor 2 | 70 p-ISSN: 2622-9641 e-ISSN: 2655-1276

Basri, S., \& Khatimah, H. (2019). Efektivitas Penggunaan Media Pembelajaran Sparkol Videoscribe terhadap Hasil Belajar Fisika Peserta Didik Kelas XI SMA Negeri 6 Jeneponto. Karst: JURNAL PENDIDIKAN FISIKA DAN TERAPANNYA, 2(2), 85-90.

Deliany, dkk. 2019. Penerapan Multimedia Interaktif untuk Meningkatkan Pemahaman Konsep IPA Peserta Didik di Sekolah Dasar. Jurnal Educare Vol. 17 No. 2 Desember 2019, hal. 91-97.

Irawan, Akhsan,dkk. 2011. Upaya meningkatkan hasil belajar fisika melalui penerapan pendekatan kontekstual pada siswa kelas VIII $_{A}$ SMP Guppi Samata kabupaten gowa. Jurnal Pendidikan Fisika Vol.1, 63-70.

Johnson, Elaine. 2006. Contextual Teaching \& Learning. Bandung: MLC

Komalasari, K. 2011. Pembelajaran Kontekstual: Konsep dan Aplikasi. Bandung: Refika Aditama.
Muchith, Saekhan. 2008. Pembelajaran Kontekstual. Semarang: Rasail

Muniarti, Wien \& Sugiharshono. 2014. Penerapan Pendekatan Kontekstual Berbantuan Media untuk Peningkatan Kualitas Pembelajaran IPS. Jurnal Ilmu-ilmu social Mei 2014 , Vol. 11, No. 1 ,hal 87-103.

Nurjamilah, Sulaeman, N. F., \& Komariyah, L. 2017. Pengguan instrumen ordered multiple choice (omc) untuk menilai pemahaman konsep usaha dan energi dengan model pembelajaran discovery di SMAN 1 Long Kali. Berkala Ilmiah Pendidikan Fisika, 5(3), 241-253

Rizkyanda, N., \& Jamal, M. A. .2013. Meningkatkan pemahaman konsep siswa melalui model pembelajaran berbasis fenomena $(P B F)$. Berkala Ilmiah Pendidikan Fisika, 1(1), 60-69

Sudjana, N. 2011. Dasar-dasar proses belajar mengajar. Bandung: Sinar Baru Algensindo.

Suyidno \& Jamal, M.A. 2012. Strategi belajar mengajar. Banjarmasin: Nusa Media bandung 